\title{
AN ANALYSIS OF LANGUAGE IMPAIRMENT OF AUTISM IN LIFE, ANIMATED FILM
}

\author{
Abdul, Kholiq, Dian Luthfiyati, Nur Dian Tamimih \\ abdulkholiq@unisla.ac.id, dian.luthfiyati@unisla.ac.id, nurdianata5@gmail.com \\ English Language Education Department, Faculty of Teacher Training and Education, Universitas Islam \\ Lamongan
}

\begin{abstract}
The aims of this study were to find language impairment of autism in Life, Animated film. The autistic child in this film is the second son of Suskind Family This study the writer uses descriptive analysis techniques. The data of this study are the conversation of Life, Animated film. Data analysis techniques used in this study is transcription, classification and analysis. Data source was Life, Animated Film. This study only focused on language impairment. The result of this study shows that Owen language impairments are Owen was confused or needed a help if he have to answer but he was forgotten. His articulation sometimes can be fast or slow, especially when Owen talked with Emily, he articulated slower than usual. He often use word "great" because his vocabularies are low, he confused to understand other people, he was echolalia, his articulation is delay and he like something scripted, but he did not confuse in using pronoun and grammatical.
\end{abstract}

Keywords: Language impairment, autism, life, animated film

\section{INTRODUCTION}

Human beings are social individual who need language as their communication to connect and cooperate with other in community. Language may be expressed and understood phonologically through speech, orthographically through writing, or gesturally through sign language. (Patricia J. Prelock and Nickola Wolf Nelson, 2012, p. 1).

Typically children that diagnosed with autism may deteriorate their speech or language. The understanding of speech get impaired, either in word or in sentence that they used. Some of them difficult to articulate well, confused in gramatical and deixis and echolalia. Therefore, children with autism or autism spectrum disorder is learn to adapt themselves using their language to communication with the other people.

The combination of autism can be various, such as language delay, obsessive, stereotypy, and repetition of words (echolalia).The children were extremely aloof and autistic and they refused to being 
contacted by their parents, doctors and preferred to be alone (Baron-Cohen, 2008, p. 58-59). Autism is characterized as a “neuro- developmental" condition, meaning that it emerges from differences in brain development (Sue Fletcher-Watson \&Francesca Happé, 2019, p. 6)

Autism has complex problem and inability in language and interaction, they have a unique behavior that unreasonable such as flapping or rocking their hand, they also tend to focus in their own world. Therefore, they must get much attention and special treatment, so they are not alienated from environment, learn to communicate and connect with other people.

\section{According to Tager-Flusberg} (Rhea Paul, And Catherine Lord 2005, p. 336), Children with autism and impaired language that is similar to the phenotype found in specific language impairment. There may also be other subgroups on the autism spectrum that reflect different kinds of language disorder.
According to (Karren 2005, p. 14-

16) American Psychiatric Association : Diagnostic and Statistical Manual of Mental Disorder, Fourth edition, Text Revision (DSM-IV-TR) is the official manual used by physicians and mental health professionals for diagnosing children on the autism spectrum. A child with an ASD displays examples of the following behaviors to some degree before the age of three: qualitative impairment in social interaction; qualitative impairments in communication; restricted, repetitive, and stereotyped patterns of behavior, interests, and activities.

Qualitative impairment in social interaction is typical children show an intense interest in other children, children with ASDs often show an intense interest in objects. Compared with typical children who play together at the playground, children with ASDs will be noticeably solitary and detached, often engaged in repetitive, odd behaviors. Toddlers with ASDs don't use body language to indicate 
what they want; they don't point or reach their arms up to indicate they want to be picked up. Nor do they share what they're doing-you won't hear "Watch me!" from a child with an ASD. Other signs of social impairment include little to no eye contact, flat or unemotional facial expressions, and no real sense of empathy toward others.

\section{Qualitative Impairments in}

Communication related may children with ASDs may have no speech, delayed speech, or idiosyncratic or repetitive speech. It has been estimated that 40 percent or more of children with ASDs do not speak at all. Those who can speak may be unable to initiate or hold a two-way conversation. Another sign of communication impairment is being unable to engage in make-believe play, which involves nonverbal communication (e.g., extending the arms out to the sides while pretending to be an airplane) and verbal communication (e.g., making airplane sounds).
Restricted, Repetitive, and Stereotyped Patterns of Behavior, Interests, and Activities may children with ASDs may obsess about a certain topic (e.g., trains or bus schedules) or object (e.g., piece of string or bottle cap) to the point where nothing or no one else seems to exist. They may have a tendency to fixate on a specific routine or ritual (e.g., touching each wall of the bedroom before bedtime), have stereotyped or repetitive actions or movements (e.g., hand flapping or rocking) known as stereotypes, or fixate on parts of objects (e.g., wheels of a toy car). Children also may have heightened sensitivities to certain sounds, sights, smells, tastes, or textures (e.g., insisting on wearing only certain clothes or eating only certain foods). Therefore, autism has significant differences, autism does not interest with getting interaction, has stereotypes and repetitive behavior. Autism also becomes annoyed easily, when their situation is uncomfortable. 
Language and communication are significant in social interaction. Language must be expressed and understood by other people. People usually speech or using gesture through sign language to express their language. Social interaction happens when individuals doing action that cause reaction to other individuals. Without involving communication, people cannot commit their daily activity.

Some of children with autism cannot produce oral communication and articulate well because restrictiveness in language. Half of all the autistic population is affected by one type of language impairment or other. This language impairment covers almost every aspect of language, for example pragmatic, syntactic, lexical, phonological, morphological, phonetics and so on (Belkadi, 2006, p. 3, Kjelgaard \& Tager-Flusberg, 2001, p. 2)

Besides that, children with autism lack of communication and it can be obstruct their language development, so, they cannot progress to improve their language. They have problems when interacting with the other people because they are deficient in making conversation. They accustomed to interact and relate with object around them. As the autistic children fail to do so, they cannot get themselves into any conversation or cannot continue a conversation. The language and the communication problem can be diagnosed with "A triad of impairments - impairments in social interaction, impairments in verbal and non verbal communication and an inappropriately restrictive behavior" (Belkadi, 2006, p. 3).

In the language impairment of autism aspect, language development in autistic children can be explored in comparison to typical development and equivalent implications for language. The types on the language impairment of autism are 1) language regression; 2) articulation; 3) word use; 4) syntax and morphology; 5) echolalia; 6) reading; 7) use of deictic terms. 
Life, Animated film is that told about autism, since Owen was child he loved to watch Disney Animated Movies with his older brother, he really enjoyed the Disney Animated Movies. He has played the Disney Films many times, sometimes he imitates the conversation of the films and scenes that is interesting for him and have an imagination which about the Disney movie. As example when he was child, he played the part scene when Peter Pan chasing Captain Hook with his dad. He has older brother and his name is Walter, Walter is 26 years old.

However, his parents have educated him and give more attention, but they were scared and afraid about Owen. He has through difficult time to learn and try his best, he want to prove to the world that he can do what normal people do, he tried the possible way in order to connect with other people.

There are some previous studies which may have similar discussion with the present study. However, some of them discussed about children with autism, communication and linguistic impairment especially language disorder.

Islam (2013), A Study of the Communicative and Linguistic Impairments of the Autistic Children. She uses mixed and triangulation methods were used to find out about the communicative and linguistic impairments of the autistic kids. These children have problems in phonology, syntax, semantics, and morphology. Again, they also experience different types of difficulties in their everyday discourse. The lack of the theory of mind is considered to be one of the most significant reasons behind their communication impairments.

Dewi (2014), Identification of Autism's Language Ability in Inclusive School SDN Giwangan, Yogyakarta. She uses qualitative research method. She describes active/expressive language in Inclusive School SDN Giwangan, 
Yogyakarta and improving efforts that doing by GPK in Inclusive School SDN Giwangan, Yogyakarta.

There are some differences between this research and the previous study. The first difference is studying on psychological problem and social interaction to understand language impairment. Meanwhile, Dewi's research Language Ability in Inclusive School. This research object is Autism in Documenter Film “Life, Animated".

Based on the explanation above, the study is to know the language impairment of autistic children in Life, Animated Film.

From the explanation above the writer conclude that autism has language impairment that cause obstruction in social interaction development, communication and language. So, it can make the children life in his own world.

\section{RESEARCH METHOD}

This study that makes in this research is design qualitative research which includes the method to be used what data will be gathered. Qualitative method used to get depth data. Therefore, in qualitative research more emphasize in meaning than generalization, (Sugiyono, 2015, p. 14-15).In order to the writer get the data, the writer should explore wide and depth about social interaction in autism.

Using document for data collecting technique. According to (Donald Ary, Lucy C. Jacobs, Chris Sorensen,2010: 442) states that the data collection of this research uses document. In documents qualitative, researcher should use documents to gain an understanding of the phenomenon under study. The term documents refer to a wide range of written, physical, and visual materials, including what other authors may term artifacts.

Data analysis technique of this study using five steps, they are transcription, codification, classification, tabulation and analysis. 
Transcription is written that transcribing from audio or video. I should be familiar with the data through watching the video and reading transcript and making note from the conversation. Transcriptions should be made of all data, including taperecorded interviews, focus groups, video recordings, and handwritten field notes. (Donald Ary, Lucy C. Jacobs, Chris Sorensen,2010, p. 481). To transcript every conversation in Life, Animated Film.

Classification is process to classify the data into groups according to each type Analysis is process of exploring and conducting systematically the data obtained by organizing the data, differentiating the data, classified into categories, and interpreted the data.

\section{RESULT AND DISCUSSION}

In this film, Ron Suskind and Cornelia have two sons, and Owen is his second son with special need. Owen was 23 years old and he will be graduating in a month and he will be living in his own apartment. Since he was child he loved to watch Disney Animated Movies with his older brother, he really enjoyed the Disney Animated Movies. He has played the Disney Films many times, sometimes he imitates the conversation of the films and scenes that is interesting for him and have an imagination which about the Disney movie. As example when he was child, he played the part scene when Peter Pan chasing Captain Hook with his dad. He has older brother and his name is Walter, Walter is 26 years old.

However, his parents have educated him and give more attention, but they were scared and afraid about Owen. He has through difficult time to learn and try his best, he want to prove to the world that he can do what normal people do, he tried the possible way in order to connect with other people.

The results of the data analysis are divided into analysis and table. The data are 
found through transcription, codification, classification, and analysis.

\section{Language Impairment in Autistic}

Children

Language regression

Children with autism had definite vocabularies and they had language delay because their language development was down and every child has different way in communication.

1) Owen confused to answer the question

2) Owen need to find something .

3) His speech was still very limited

4) I'm right... I'm home, my new home

5) Owen confused when he write for his speech in France

From the data above, it can be concluded that according to his mother, Cornelia, Owen's motor skills were deteriorating and then his language processing broke down he just started reciting this gibberish. So, it can be concluded that Owen get more vocabularies because he learn from movie. So, Owen has problem with his Language and communicate well with the other people.

\section{Articulation}

Articulation

development

becomes normal or slower, because they have difficulties to articulate well. So, articulation in autistic children can be fast and slow.

1) Owen Confused to convey his opinion "Still great, but a little ...Different"

2) Owen said "I don't remember" with stammering

3) Become slower if Owen have a talk with Emily

4) Owen tells about Fuzzbutch "to make the...world look like a weird place to them"

From the data above, it can be seen that Owen articulated the sentence did not fluently. Sometimes his intonation became high and fast. If Owen talked with Emily, he became articulate slower and calm than talk with his parents, his brother or talk with other people.

\section{Word Use}


Autistic has a few vocabularies because they fail to use the words in communication. So, they often use the same word because they are difficult to enrich vocabulary.

1) Owen often to use word "great" (49/S00:04:23 - 00:04:25, 691/S-00:51:36 - 00:51:39, 801/S-01:00:55 01:00:58, 817/S-01:02:19 - 01:02:22, 979/S-01:06:29 - 01:06:32, 1090/S01:24:06-01:24:07)

Owen used word "great" frequently and becomes habitual. Especially when the other person said "good", automatically Owen also said "great".

\section{Syntax and Morphology}

Owen used correct grammar and appropriate morphology in his language. So, Owen did not confused when differentiate tenses and carried away by the words that spoken by the other person.

\section{Echolalia}

Most of children with autism had echolalia. Echolalia is one of characteristic that find in verbal autistic children and children with apraxia. Echolalia is part of language development and how children learn language.

1) Owen spoke sort of gibberish "juicervoce, juicervoce, juicervoce"

2) Owen dart so fast and answered his mother “yeah, yeah. Let's go, let's go, let's go

3) Owen tried to swim, but he was fear, he waved his hand and said "I am in, I am in" and "I swam to you, I swam to you" )

4) After Owen taken his diploma in his graduation he said "yay, I did it. Yay, I did it"

5) Walter visited his brother. Owen see from his window and scream "Walter!, Walt's here!, Walt's here!,Walt

From the data above it can be concluded that Owen had echolalia when he was three years old when he was watched 
The Little Mermaid has to trade something to be human. Now, Owen still echolalia but it was happen when he was in happy or unpleasant situation, Owen still echolalia until he is adult because echolalia is characteristic of Autism children or people.

\section{Reading}

Autistic children increase their social and communication with written script, cards, and social stories.

1) Owen really likes things scripted

Michelle Gracia as Owen social thinking evaluator conveyed after she was giving the things that hard for Owen, because is not easy to talk to other people. Then she said that "Owen really likes thing scripted".

\section{Use of Deictic Terms}

Owen did not confuse to use personal pronoun or labeling person by their name.

The discussion of this study are Owen language impairments are Owen was confused or needed a help if he have to answer but he was forgotten. His articulation sometimes can be fast or slow, especially when Owen talked with Emily, Owen articulated slower than usual. Owen often use word "great" because his vocabularies are low. Most of the words he uttered were echolalia, and Owen like reading, he like something scripted, because it easy to remember.

Based on the result, Owen did not confuse when using pronoun and grammatical. He knows when he is out in the community, making appointments and having to find location. He knows he what posture for walking through community. He can answered question but he imitating to ask the same question, sometimes he knows the answer but difficult to present what he meant. He can make perfect comment that evaluate and controlled by Michelle. Things that are unpredictable make their folks really anxious (Michelle Garcia Winner. Owen's social evaluator)

He can make short narrative storytelling with his imagination using Disney Animated movie, he makes his own 
life stories as the main character in his stories, and link with all of Disney movie that he ever watched. Tager- Flusberg in Fred R. Volkmar (2005) states that stories of children with autism and mental retardation were shorter and less complex and contained fewer causal statements and that they were less likely to include a resolution or introduce new characters.

\section{CONCLUSION}

The language impairment of autism found in Life, Animated film is Owen was echolalia. Owen also repeated his word and delay in language, although his vocabulary is not restrictive but he often using word "great". Sometimes his articulation is changing, especially when he talks with Emily, he will be talk slower than usual.

The conclusion of the above result explains that Owen was supported by his parents, his family and therapist to figure out and cover Owen in his communication especially when use language in to communicate.

The important things to note that language is about how individual learn to communicate and use their passion, how far they are able mastering the language or not cannot become measurement to be invited to communication and interaction. Autistic has ability to speech and expresses their emotion if people understand what autistic try to convey.

Therefore, after explaining about Language Impairment of Autistic Children in Life, Animated Film, the result is expected to give contribution on the social interaction in autistic children especially Finally this study shows that autistic children want to be around people, they want what everyone else want, but they are sometimes misguided and do not know how to connect with others.

\section{REFERENCES}

Ary, Donald et al. 2010. Introduction to Research in Education (Eighth Edition). Canada.Wdsworth. 
Baron- Cohen, Simon. 2008. Autism and Asperger Syndrome (First Edition). Oxford, New York

Belkadi, A. 2006. Language impairments in autism: evidence against mindblindness. SOAS Working Papers in Linguistics, 14, 3-13. Retrieved from https://www.soas.ac.uk/linguistics/re search/workingpapers/volume14/file37813.pdf

Fletcher-Watson, Sue, \& Happé, Francesca. 2019. Autism: A New Introduction to Psychological Theory and Current Debate. Routledge 52 Vanderbilt Avenue, New York, NY 10017

Prelock, Patricia J. and Nelson, Nickola W. 2012. Language and Communication in Autism: An Integrated View Exkorn. F. 2005. The Autism Sourcebook. New York: HarperCollins Publishers Inc.

Tager-Flusberg, H., Paul, R., \& Lord, C. 2005. Language and communication in autism. Fred R. Volkmar et al (Eds.), Handbook of autism and pervasive developmental disorder. Third Edition). Vol. 1. Printed in the United States of America, Canada

Sugiyono. 2015. Metode Penelitian Pendidikan Pendekatan Kuantitatif, Kualitatif, dan R\&D. Bandung: Alfabeta.

www.lifeanimateddoc.com synopsis of Life, Animated Film Retrieved 19 Februari 2019 